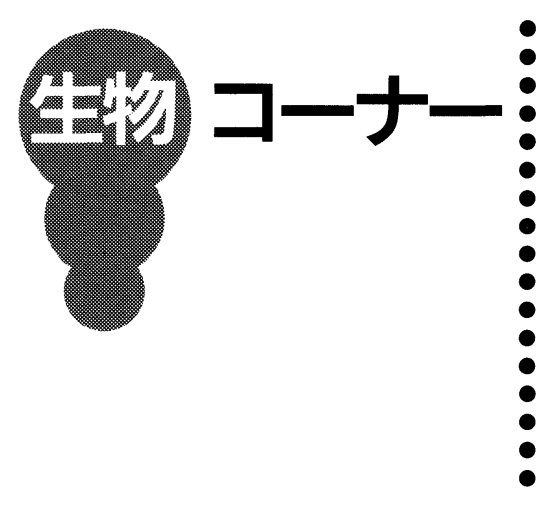

RNA 型植物ウイルスのゲノムは, 比較的小さいこと(最もゲノムサイズ が大きいイネ萎縮ウイルスでも約 24,000 塩基) や, RNA の cDNA クロ ーニングが簡単になったこともあっ て，そのほとんどのゲノム構造がすで にわかっている. そのため, 植物ウイ ルスの生物学もすべての研究領域で塩 基配列を基本に考えられるようになっ てきた。たとえば，それまで同じウイ ルスと思われていたものが，塩基配列 を調べてみると実は違うウイルスであ ったり, あるいは一つの純粋な分離株 と思われていたものが，塩基配列の上 では複数の変異株が混じっていたりす ることが明らかになってきた。

また, 多くの RNA ウイルスでは, ゲ ノムが分節しているものが多い.つま り, 遺伝子を複数の RNA 分子に分散 させており，これらの RNA 分子がセ ットになってはじめて, ウイルスが感 染・増殖できる。

イネ萎縮ウイルスは, ツマグロヨコ バイによりイネからイネに伝搬され， 植物と媒介昆虫の両宿主で増殖できる 植物ウイルスである.そのゲノムは二 本鎖の RNA で，12 本に分節（ゲノム セグメント）しており, 電気泳動移動 度の遅いものから $\mathrm{S} 1$ S 12 と呼ばれ

\title{
イネ菱縮ウイルスと ッマグロヨコバイ
}

る.ゲノムセグメントの大きさは S1 で 4,423 塩基対, S12 で 1,066 塩基対 である、筆者はイネ萎縮ウイルスの研 究を続けながら, 最近このウイルスが 思ったよりゲノムの変異に富んでお り，またうまく媒介昆虫とイネの間を 渡り歩いていることに感心している. 本稿では，こうした研究の一端を紹介 したい.

\section{ㄴำイネ菱縮ウイルスの自然界での 生活環 \\ $\bullet \bullet \bullet \bullet \bullet \bullet \bullet \bullet \bullet \bullet \bullet \bullet \bullet \bullet \bullet \bullet \bullet \bullet \bullet \bullet$} イネ萎縮ウイルスがどうやって自然 界で存続しているのかは, 宿主である ツマグロヨコバイの生活環とイネの栽 培法に密接に関係している. イネが春 に田植えされると, 畦道で越冬してい たツマグロヨコバイが一斉に幼苗に移 ってくる.このときイネ萎縮ウイルス を保毒した虫は, イネにウイルスを伝 搬する.イネの生育後期では，ウイル スは感染しにくくなるので, 田植え直 後がウイルス感染に最も重要である. 感染したイネはウイルス感染源とな り, 虫を介してさらにウイルスが伝搬 される、秋にイネが刚り取られると虫 は畦道の雑草に移動する.すなわち, 畦道で越冬するツマグロヨコバイの中
で，ウイルスは越年することになる。 温暖な地方ではイネが通年栽培され， ツマグロヨコバイとイネの両宿主でウ イルスは増殖と伝搬を繰り返す。

\section{罂性}

イネ萎縮ウイルスの 12 本に分節し たゲノムセグメントは，セットとして 1 つのウイルス粒子内に入っている. ウイルス粒子からゲノム核酸を抽出し てポリアクリルアミドゲルで電気泳動 すると，これらのゲノムセグメントを 分離できる.イネ萎縮ウイルスに感染 したイネを田圃から採集してきて，感 染株毎にウイルスの核酸を抽出して電 気泳動にかけると, ゲノムセグメント の電気泳動移動度がわずかに異なるウ イルスが見つかった.たとえ同じ田圃 から採集したイネでもそのほとんど で, 12 本のゲノムセグメントのうち, いずれかが異なる移動度を示してい た (1) (図 1). 塩基配列を調べると，これ らの移動度の違いは, 数塩基の置換で 起こっており, 塩基数の違いではなか った.二本鎖の RNA では，アクリル アミド電気泳動移動度の差が一塩基の 置換でも起こることを筆者の研究室で 


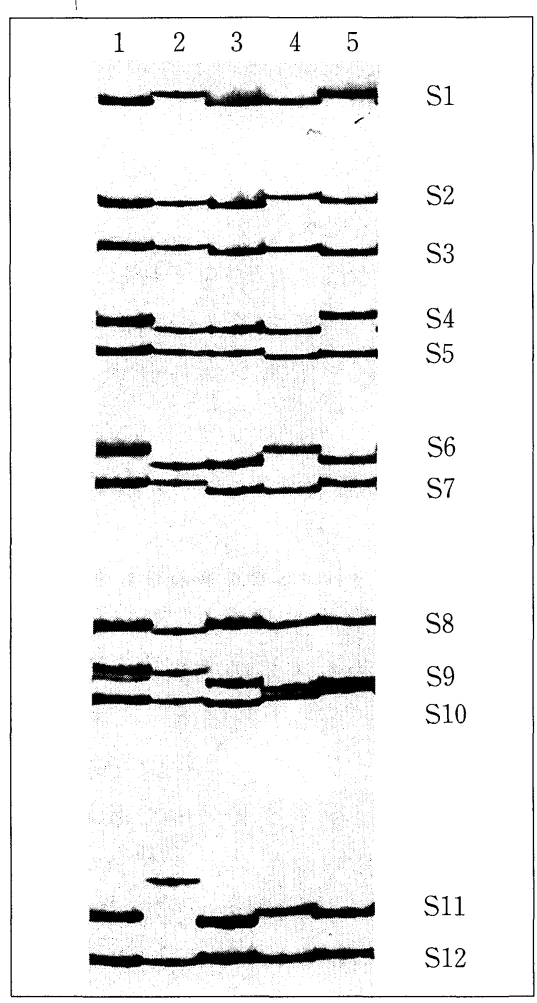

図 1 -イネ萎縮ウイルスゲノムの 多様性

同じ田戋からイネ萎縮ウイルスに感染した イネを採集し，個体毎にウイルスのゲノム 二本鎖 RNA を抽出し，ポリアクリルアミ ドゲル電気泳動にかけた。右側にゲノムセ グメントの番号を示した.イネ毎のウイル ス集団間で，対応するゲノムセグメントの 移動度がわずかに異なっているのがわか る. レーン 1 の感染株の S9 で, 2 本のバン ドが確認でき，へテロなウイルス集団であ ることがわかる.

証明していたので，このことはある程 度予想されていたが，同じ 1 枚の田圃
にいるウイルスでも, 感染するイネ毎 に皆異なる塩基配列をもっていること は驚きであった。

\section{근 昆虫で媒介されるにはウイルス の特定の遗伝子が働いている

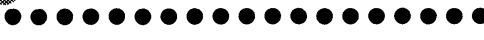

こうしたゲノムの多様性から，イネ 萎縮ウイルスでの遺伝学が可能になっ た.すなわち，それぞれのウイルス分 離株が固有の “顔”を遺伝子レベルて もつから，2つのウイルス株から合い の子ウイルスができたときに，親から 受け継いだゲノムセグメントが電気泳 動で簡単に同定できる ${ }^{(2)}$ (図 2).

まず, 12 本のゲノムセグメントがす べて電気泳動で区別できる 2 つ分離 株を選んで，両方を混ぜたウイルス液 を媒介昆虫のツマグロヨコバイに注射 する.すると，両方のウイルス株とも 虫体内の同一細胞で増殖するが，子孫 ウイルスができるときに，両親のゲ， ムセグメントがキメラ状態で粒子に取 り込まれる.つまり, 12 本のゲノムセ グメントのそれぞれは必ず片方の親か らしか 1 つの粒子に入らないので，1 セットのゲノムセグメントの幾つかが 片方の親から, 残りはもう一方の親か らで構成される合いの子ウイルスがで き(遺伝的再集合)，しかもその組合せ はランダムに起こる。いろいろな組合 せの合いの子ウイルスを単離するの も, 思ったより簡単であった。保毒し
た一頭の媒介昆虫にイネを数時間吸汁 させると, わずか数個のウイルス粒子 で感染が成立する。そこで, ウイルス の伝搬をさらに数回繰り返すと, 純粋 な合いの子ウイルスを分離することが できた。

遺伝的再集合を利用した遺伝学を使 って, 媒介昆虫の特異性を決定してい るウイルス遺伝子の同定が可能であ る. 中国で採集したイネ萎縮ウイルス は, 日本のツマグロヨコバイに注射す ると虫体内で増殖することはできて も, ウイルスをイネに伝搬することは できない.そこで, ツマグロヨコバイ でよく伝搬する日本の分離株と遺伝的 再集合株を作り，S10のみを日本の分 離株と入れ替えるだけで, 中国のウイ ルスは媒介昆虫で伝搬されるようにな った。もちろん, 中国ではこのウイル スを媒介するツマグロヨコバイがいる わけだから, 虫の系統のわずかな違い が昆虫媒介の特異性を決めていること になる。また，フィリピンのイネ萎縮 ウイルスは, 日本のツマグロヨコバイ に注射しても虫体内で増殖すらできな い. しかし S1 と S6 を日本の伝搬株と 入れ替えると伝搬されるようになる。 この場合, S10 はフィリピンのウイル ス遺伝子でも伝搬可能であった. 

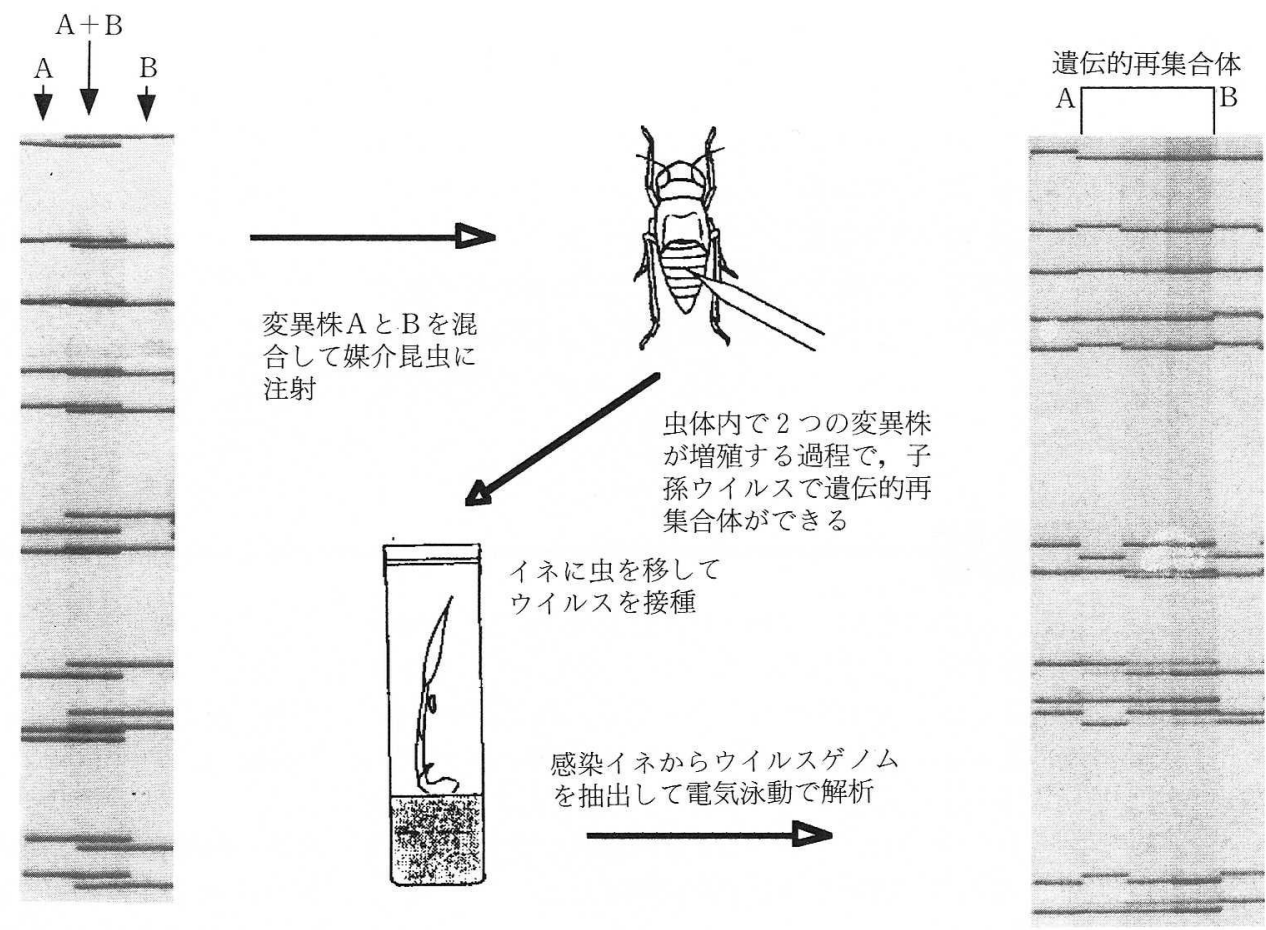

図 2 遺伝的再集合体の作製

すべてのゲノムセグメントが電気泳動移動度で区別できるウイルス変異株(左側の電気泳動図) を混合して媒介昆虫に注射すると, 虫体内で 子孫ウイルスは，遺伝的再集合を起こして 2 つの変異株の合いの子ウイルスとなる. 感染したイネからウイルスのゲ/ムを抽出して電気泳 動にかけると(右側の電気泳動図)遺伝的再集合体の 12 本のゲノムセグメントについて，親の由来がわかる.

イネ菱縮ウイルスにとっでツマ グロヨコバイは遺伝子シャッフ ルの場である

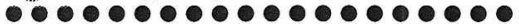

つ一つのイネに感染しているウイ

ルス集団のゲノムを電気泳動で調べる

と，比較的単一のゲノムをもつ集団か

ら成り立っている。それなのに，なぜ

同じ田圃の中の感染イネ間で皆異なる
ゲノム変異株が存在するのだろうか。 今は病害の防除体系がしっかりしてい るので, 田圃のウイルス感染イネは, 多くても数パーセントに過ぎない。し たがって，イネがウイルスに多重感染 する頻度は低く，イネが遺伝的再集合 の場になる可能性は低い。おそらく， ツマグロヨコバイの中で遺伝的再集合
が起きているのであろう。

たとえば，それぞれに異なるゲノム 変異株をもつ 2 つの感染イネが存在す るとすると，媒介昆虫が両方のイネか らウイルスを獲得すると, 虫体内で 2 つの変異株が同時に増殖する。ウイル ス粒子が成熟する過程で, 12 本のゲ， ムセグメントが両変異株からランダム

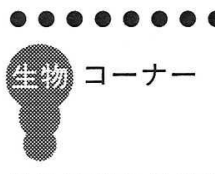


に組み合わされた様々な遺伝的再集合 体が多数できる. 媒介昆虫がイネにウ イルスを感染させるにはわずかな粒子 数で(極端な場合は 1 粒子で)十分なの で, 多数の遺伝的再集合体のうち, 数 種類だけが感染イネで増殖することに なる.したがって，2つの変異株が遺 伝的再集合を起こすと組合せ的に無数 の変異株が誕生することになる.
こうしてウイルスは，塩基置換の蓄 積による変異だけでなく, ゲノムセグ メントを交換しながら変わることもで きる，前述のように，たとえ媒介昆虫 で伝搬できなくなったウイルスが変異 で出現したとしても, 虫体内で遺伝的 再集合が可能なら，欠陷遺伝子だけを 交換すれば他の遺伝子は存続可能とな る. イネ萎縮ウイルスは, こうして変
異と遺伝的再集合を繰り返してうまく 環境に適応しているのである.

1) K. Murao, N. Suda, I. Uyeda, M. Isogai, H. Suga, N. Yamada, I. Kimura \& E. Shikata : J. Gen. Virol., 75, 1843 (1994).

2) I. Uyeda, Y. Ando, K. Murao \& I. Kimura: Virology, 212, 724 (1995).

(上田一郎, 北海道大学農学部)

\section{ロフ ル}

浅島 誠 (Makoto Asashima) 昭和 19 年 9 月 6 日生 $<$ 略歴 $>$ 昭和 42 年東京 教育大学理学部動物学科卒業 $/ 47$ 年東 京大学大学院理学系研究科博士課程修 了/同年ドイッ・ベルリン自由大学分子 生物学研究所研究員 $/ 49$ 年横浜市立大 学文理学部助教授 $/ 60$ 年同教授 /平成 5 年東京大学大学院総合文化研究科教授, 現在にいたるく研究テーマと抱負 > 動物 の初期発生における形づくりと器官形成 のしくみを解明したいく趣味 $>$ 読書と散 策

芦田 久 (Hisashi Ashida) 昭和 39 年 4 月 15 日生 $<$ 略歴 $>$ 昭和 63 年京都大 学農学部食品工学科卒業/同年ヒガシマ ル醬油(株) 入社 $/$ 平成 5 年(株) 京都第一 科学入社 $/ 9$ 年京都大学大学院農学研究 科研究生, 現在にいたる<研究テーマと 抱負>微生物のエンドグリコシダーゼを 用いた糖鎖工学的研究. 微生物と他の生 物の関わり合いを調べることく趣味 $>$ 昆 虫の研究（特にハンミョウとチビゴミム シの分類と生態),ケイビング(洞窟探検)

荒 木 亘 (Wataru Araki) 昭和 32 年 12 月 16 日生 $<$ 略歴 $>1985$ 年京都大学医 学部医学科卒業／同年同大学にて内科・ 神経内科臨床研修 ( 88 年) / 1992 年同 大学大学院医学研究科博士課程修了／同
年国立精神・神経センター神経研究所研 究員/1995 年米国マサチューセッツ工 科大学ポスドク／1997 年国立精神・神経 センター神経研究所研究員 /1998年同 室長，現在にいたるく研究テーマと抱 負 >アルツハイマー病および他の神経変 性疾患の分子病態解明など

上田 一郎 (Ichiro Uyeda) 昭和 25 年 3 月 23 日生 $<$ 略歴 $>$ 昭和 47 年北海道大 学農学部農業生物学科卒業/53 年米国 ワシントン州立大学博士課程修了(植物 病理) /同年北海道大学農学部助手 $/ 57$ 年同助教授 /平成 7 年同教授，現在にい たるく研究テーマと抱負 > 植物ウイルス の植物発現ベクター化, RNA レプリコ ンの分子生物学<趣味 > 釣り, テニス

小栗 秀 (Suguru Oguri) 昭和 41 年 7 月 6 日生 $<$ 略歴 $>1989$ 年玉川大学農学 部農芸化学科卒業／1991 年千葉大学大 学院農芸化学専攻修士課程修了/1994 年同自然科学研究科博士課程修了/同年 キリンビール (株) 基盤技術研究所糖鎖工 学ポスドク／1995 年東京農業大学生物 産業学部(オホーツク・キャンパス)助 手 $/ 1998$ 年同講師, 現在にいたるく研究 テーマと抱負 $>$ 動・植物の糖鎖生合成に 関する研究・糖鎖と糖鎖認識タンパク質 (レクチン)の役割解明 <趣味 $>$ 網走の豊
かな自然を楽しんでいます

小俣 達男 (Tatsuo Omata) Vol. 34, No. 9 , p. 594 参照

大川 秀郎（Hideo Ohkawa） 昭和 15 年 9 月 10 日生 $<$ 略歴 $>$ 昭和 44 年九州大 学大学院農学研究科博士課程修了(農 博) /同年米国カリフォルニア大学バー クレー校博士研究員 ( 46 年) $/ 47$ 年住 友化学工業(株)宝塚研究所勤務/平成 3 年神戸大学農学部教授, 現在にいたる <研究テーマと抱負> (1)薬物代謝型 P450を発現したトランスジェニック植 物，(2)花芽特異的に発現している P450 分子種, (3)残留農薬の免疫測定法 $<$ 趣 味>山歩きと読書

太田 大策（Daisaku Ohta）昭和 33 年 5 月 19 日生 $<$ 略歴 $>$ 昭和 58 年京都大学 農学部農芸化学科卒業 $/ 60$ 年同大学大 学院農学研究科修士課程修了/63 年同 博士課程修了(農博) /同年日本チバガイ ギー(株) 国際科学研究所研究員 /平成 9 年岡山県生物科学総合研究所勤務 $/ 10$ 年大阪府立大学農学部助教授, 現在にい たる<研究テーマと抱負 $>N O$, 活性酸 素, 抗酸化機構と遺伝子発現調節 $<$ 趣 味>心拍トレーニング 